Crop Breeding and Applied Biotechnology 15: 175-180, 2015

Brazilian Society of Plant Breeding. Printed in Brazil

NOTE

http://dx.doi.org/10.1590/1984-70332015v15n3n30

\title{
Yield, market quality, and leaf spots partial resistance of interspecific peanut progenies
}

Taís de Moraes Falleiro Suassuna ${ }^{1}$, Nelson Dias Suassuna ${ }^{1 *}$, Márcio de Carvalho Moretzsohn ${ }^{2}$, Soraya Cristina de Macedo Leal Bertioli ${ }^{2}$, David Jonh Bertioli ${ }^{3}$ and Everaldo Paulo de Medeiros ${ }^{1}$

Received 19 September 2014

Accepted 08 April 2015

\begin{abstract}
Development of leaf spots resistant runner peanut cultivars is one of the major demands in Brazil. In the 2009/10 crop season, 12 pre-breeding progenies (LPM) were selected out of 380 plants of an interspecific BC $F_{3}$ population for leaf spots resistance and agronomic traits. In the 2010/11, the 12 LPMs were evaluated for leaf spots resistance, without fungicide sprays. The recurrent parent (susceptible control) and all LPMs were susceptible; partial resistant segregating plants were selected. Some progenies had yield, pod and seed shape similar to the control. The 12, and the 5 LPMs selected in the 2011/12 and 2012/13 crop seasons, respectively, were evaluated under appropriate disease management. Differences were detected for pod yield and weight of 100 seeds. Seed/pod weight ratio, oil content and oleic/linoleic ratio were similar to the control. Individual plants were selected for pod yield and market quality. Variability detected in the first backcross generation for partial resistance and agronomic traits will be useful.
\end{abstract}

key words: Arachis sp., pre-breeding, wild relatives, oil content, O/L ratio.

\section{INTRODUCTION}

The expansion of peanut production and commercialization in Brazil can be attributed to the development of runner type cultivars, as well as to advances in crop management and industrial practices (Martins 2011). Runner cultivars in the United States and Brazil have been improved for yield, uniform maturity, pod and seed shape and size, and for processing and sensory tests, resulting in higher yield and better processing crops (Norden et al. 1969). Another important characteristic for peanut market is oleic/linoleic ratio $(\mathrm{O} / \mathrm{L})$, which confers oxidative oil stability, preventing the rancidity of high-fat products. This trait is a growing demand of the peanut edible market.

Development of leaf spots resistant cultivars is one of the main demands for this crop (Martins and Vicente 2010, Holbrook et al. 2014). Early leaf spot, caused by Passalora arachidicola (Hori) U. Braun (teleomorph: Mycosphaerella arachidis Deighton), and late leaf spot, caused by Passalora personata (Berk. \& M.A. Curtis) S.A. Khan \& M. Kamal (teleomorph: Mycosphaerella berkeleyi W.A. Jenkins), occur in peanut growing areas worldwide, causing defoliation and yield reducing in more than $50 \%$ of the crop without chemical management (Backman and Crawford 1984). The inheritance of resistance to both leaf spots is quantitative. Despite the identification of resistance sources in cultivated and wild species, there is no completely resistant commercial cultivar (Holbrook et al. 2014).

Although the use of the accessions available in germplasm banks is low (Nass et al. 2012), the initial efforts to introduce genes from wild species into cultivated peanut started in the 1970s, and were focused on leaf spots resistance (Stalker et al. 1979, Simpson et al. 1993). The laborious and time consuming process of successive backcrossings to achieve the standards of quality and yield for the peanut market is one of the main difficulties reported by peanut breeders worldwide (Ouedrago et al. 1994, Holbrook et al. 2014).

Peanut (Arachis hypogaea L.) is an allotetraploid $(2 \mathrm{n}=4 \mathrm{x}$ $=40$ ) with an $\mathrm{AB}$ genome derived from the combination of a few individuals from two wild diploid species, A. ipaënsis (B genome) and $A$. duranensis (A genome) (Kochert et al. 1996, Fávero et al. 2006, Grabiele et al. 2012, Moretzsohn

\footnotetext{
${ }^{1}$ Embrapa Algodão, Rua Oswaldo Cruz, 1.143, Centenário, CP 174, 58.428-095, Campina Grande, PB, Brazil. *E-mail: nelson.suassuna@embrapa.br

${ }^{2}$ Embrapa CENARGEN, Parque Estação Biológica, PqEB, Av. W5 Norte, CP 02372, 70.770-917, Brasília, DF, Brazil

${ }^{3}$ Universidade de Brasília, Departamento de Genética e Morfologia, Campus Darcy Ribeiro, Asa Norte, $70.910-900$ - Brasília, DF, Brazil
} 
et al. 2013). Research progress over the last few years has provided a better comprehension about the origin of cultivated peanut and its putative relatives, including the development of amphidiploids combining species of different genomes, cross-compatible to $A$. hypogaea (Fávero et al. 2006, Fávero et al. 2009, Bertioli et al. 2011). Resistance to peanut leaf spots have been identified in a large number of accessions with $\mathrm{A}$ and $\mathrm{B}$ genomes, including the wild specie A. duranensis (Fávero et al. 2009).

The present study reports the identification of runner market type peanut pre-breeding progenies, in the first backcross generation, derived from the cross Runner IAC 886 × (A. ipaënsis x A. duranensis $)^{4 x}$. Indeed, progenies with yield, oil content and $\mathrm{O} / \mathrm{L}$ ratio similar to the cultivated control used as recurrent parent are reported, and variation for seed size is discussed. The selection of leaf spots partial resistant segregating plants is also reported.

\section{MATERIAL AND METHODS}

In the 2009/2010 crop season, twelve progenies out of the 380 individual plants of a $\mathrm{BC}_{1} \mathrm{~F}_{3}$ population [Runner IAC 886 x (A. ipaënsis K30076 x A. duranensis V14167) ${ }^{4 \mathrm{x}}$ ] were selected for early and late leaf spots resistance higher than the recurrent parent (Runner IAC 886 - very susceptible), as well as for prostrate growth habit, pod yield, pod shape, pod size, seed shape, seed size and seed color (runner market type), under field conditions, at Embrapa Cerrados (lat $15^{\circ} 35^{\prime} \mathrm{S}$, long $47^{\circ} 42^{\prime} \mathrm{W}$, alt $1003 \mathrm{~m}$ asl), in the Federal District, Brazil.

The 12 selected $\mathrm{BC}_{1} \mathrm{~F}_{3: 4}$ progenies (named LPM 12 to 23) were evaluated for disease resistance in the 2010/11 crop season, at Embrapa Rice and Beans, in Santo Antônio de Goiás (la t $16^{\circ} 30^{\prime} \mathrm{S}$, long $44^{\circ} 17^{\prime} \mathrm{W}$, alt $823 \mathrm{~m}$ asl), State of Goiás , Brazil. The climate of the experimental area is tropical, megathermic savannah; the soil is Rhodic Ferralsol (heavy clay texture), previously cultivated with forage grass. Due to limited number of seeds, progenies were arranged in an augmented block design (Cruz and Carneiro 2006) with two replications and two common checks (Runner IAC-886 and a Runner local selection). Experimental plots were formed by two $2 \mathrm{~m}$ long rows $(0.76 \mathrm{~m}$ between rows and $0.10 \mathrm{~m}$ between plants). Fertilizers and calcarium were added according to soil analysis and recommendation for peanut production; fungicides were not applied to favor leaf spots progress. Disease resistance was evaluated 130 days after sowing (DAS), for both early and late leaf spots, based on foliar lesion area and defoliation grade scale proposed by Subrahmanyam (1990), varying from 1 (no symptoms) to 9 (complete defoliation). In each row, ten plants were individually evaluated and an infection intensity index (I) was calculated (Amaral 1969). The angular transformation of I permits the analysis of variance (Czermainski 1999). Plants were harvested at 135 DAS, and pod yield (extrapolated to $\mathrm{kg}$ of peanuts in shell per hectare) was recorded for each plot.

Yield and market quality evaluations were proceeded in the following crop season, without disease interference; the twelve $\mathrm{F}_{3: 5}$ progenies were tested under an augmented block design, with three replications and two common checks (Runner IAC-886 and a Runner local selection). Experimental area climate, soil and management were the same described for the disease resistance evaluation. Plots were formed by four $5 \mathrm{~m}$ long rows, spaced $0.10 \mathrm{~m}$ between plants and $0.76 \mathrm{~m}$ between rows. Plants were harvested at 140 DAS. Pod yield, weight of 100 seeds (W100S) and seed/pod weight ratio were evaluated.

Five runner type $\mathrm{F}_{3: 6}$ progenies were phenotypically selected for pod uniformity. These progenies and the cultivar IAC Runner 886 were tested in the 2012/13 crop season in Santa Helena de Goiás, southwest region of the State of Goiás, in the experimental area of Fundação Goiás. Climate and soil classification were similar to the experimental area of Embrapa Rice and Beans, except for have being previously cultivated with cotton. The experimental design was complete randomized blocks with four replications. Plots were formed by four $5 \mathrm{~m}$ long rows, spaced $0.10 \mathrm{~m}$ between plants and $0.76 \mathrm{~m}$ between rows. Fertilizers and calcarium were applied as described before, as well as disease and pest management. Plants were harvested at 140 DAS. Pod yield, W100S and seed/ pod weight ratio were evaluated.

A sample of twenty seeds from each plot of the 2011/12 and 2012/13 crop seasons was used to evaluate oil content and fatty acid composition. Oil content was determined by using a nuclear magnetic resonance spectrometer $\mathrm{H} 1$ OXFORD MQA 7005 (AOCS 2004). Oleic and linoleic acids were estimated by measuring near-infrared from 1 $\mathrm{mL}$ of peanut oil seeds. The procedure was carried out based on transflectance obtained in a NIR spectrometer (XDS тм Masterlab, Inc Foss, Höganäs, Sweden), in the Advanced Chemistry Laboratory of Embrapa Cotton, State of Paraiba, Brazil.

Analysis of variance and means grouping were carried out using the software Genes (Cruz 2006). Additionally, the following parameters were estimated: coefficients of variation, broad-sense heritability $\left(\mathrm{h}^{2}\right), \mathrm{CVg}$ and $\mathrm{CVg} /$ CVe ratio. 


\section{RESULTS AND DISCUSSION}

Favorable weather conditions for foliar disease development occurred in the 2010/11 crop season. Late leaf spot was severe, leading to intense defoliation in all LPMs, similar to the susceptible control, Runner IAC 886. No significant difference was detected for disease index (I). The intense defoliation observed in all the progenies, leading to plant evaluations with disease scores greater than 8 , showed that these progenies were not a source of high levels of leaf spots resistance. Although resistance to late leaf spot had been found in A. duranensis accession V14167 (Fávero et al. 2009), the amphidiploid used in the present study ( $A$. ipaënsis K30076 x A. duranensis V14167 ${ }^{4 \mathrm{x}}$ has only partial resistance to fungal diseases (data not shown).

Some segregating plants in the LPM 13, LPM 16, LPM 17 and LPM 21 progenies were evaluated with scores 6 (severe lesions in lower and middle leaves; less severe lesions in top leaves; extensive defoliation of lower leaves; defoliation of some leaflets evident in middle leaves) and 7 (lesions in all leaves but less severe in top leaves; defoliation of all lower and some middle leaves) (Subrahmanyam et al. 1990). Considering that the recurrent parent exhibited high severity, the partial resistance observed in these plants can be attributed to genes inherited from the wild species of the amphidiploid used as donor parent. These segregating plants were cloned before harvest and will be used as a source of partial resistance. Leaf spots partial resistant germplasm lines were developed (Stalker et al. 2002, Isleib et al. 2006) based on the interspecific population A. hypogaea $\mathrm{x}$ A. cardenasii (Stalker et al. 1979). The germplasm line N96076L was used in the breeding of the partial resistant cultivar Bailey (Isleib et al. 2011), which requires a reducedcost fungicide program (Holbrook et al. 2014). The partial resistant plants selected in the present article were crossed with high yielding/partial resistant cultivars, generating new breeding populations, aiming to select transgressive resistant genotypes in future evaluations.

There was no difference for pod yield $(\mathrm{P}=0.423)$ in the 2010/11 evaluation (Table 1). This trait was low in all treatments, including the cultivated control Runner IAC 886 , due to intense defoliation caused by early and late leaf spots. Furthermore, maturity, growth habit, pod shape, seed shape, pod size, seed size and seed color were similar to the runner cultivar used as control. These observations encour-

Table 1. Means, summary of the analysis of variance and genetic parameters for disease index (I), pod yield and market quality evaluations of twelve peanut interspecific progenies

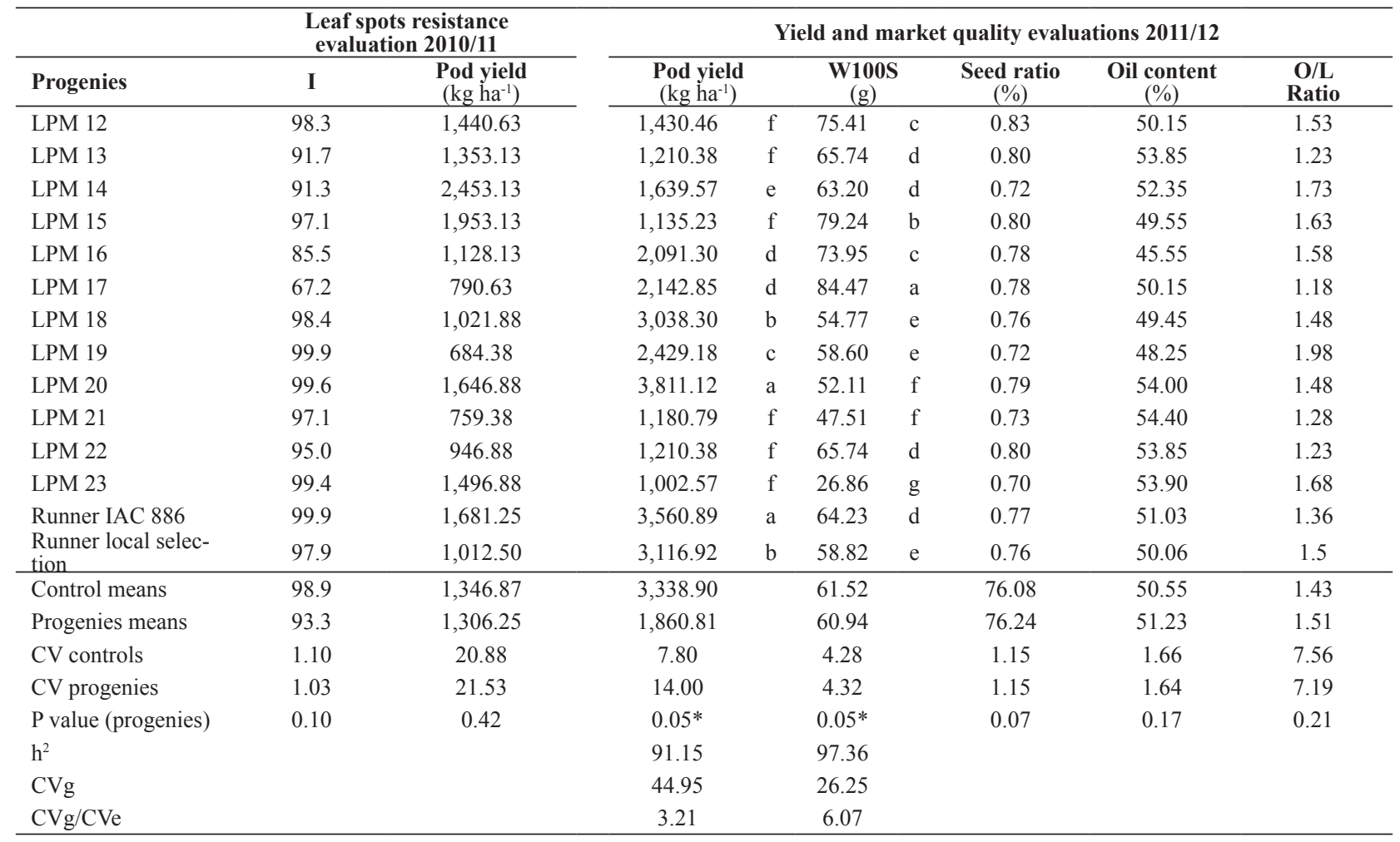

* Significant at 5\%; Means followed by the same letter in the same column belong to the same group by the Scott-Knott test at 5\% of probability. 
aged the evaluation of these progenies under appropriate disease management for pod yield and market quality, in the following season.

Pod yield and W100S had significant effect $(\mathrm{P}=0.05)$ in the 2011/12 crop season evaluation. No significant differences were observed for seed ratio, oil content and O/L ratio (Table 1), indicating that processing qualities of these progenies are similar to the runner cultivar used as control. The CVs were relatively low for pod yield, W100S, seed ratio, oil content and $\mathrm{O} / \mathrm{L}$ ratio. Progenies were classified in six groups for pod yield (Table 1). The group with the highest pod yield was formed by LPM $20(3,811.12 \mathrm{~kg}$ $\left.\mathrm{ha}^{-1}\right)$ and the cultivar used as control in this experiment, IAC Runner $886\left(3,560.89 \mathrm{~kg} \mathrm{ha}^{-1}\right)$. These values are close to those observed in commercial fields with runner type varieties in Brazil. Another control (Runner selection) and LPM 18 had pod yield higher than other treatments (over $3,000 \mathrm{~kg} \mathrm{ha}^{-1}$ ) (Table 1).

The grouping means test classified the progenies in seven groups for W100S, with means ranging from 26.86 to 84.47 g. (Table 1). Seed weight is important to classify genotypes according to seed size for market. W100S between 50 and 70 is considered Runner market type, an international pattern for peanut commercialization; W100S higher than 70 is considered Jumbo type, a specific market for snacks. LPM 13, LPM 14, LPM 19, LPM 18 and LPM 20 progenies could be classified as runner market type, while LPM 15, LPM 12, LPM16 and LPM 17 could be considered as large seed progenies, or Jumbo (Table 1). The W100S of the recurrent parent was $64.23 \mathrm{~g}$.; therefore, seed size of the jumbo type progenies can be attributed to transgressive segregation for this trait. The same was observed by Stalker et al. (1979), who reported that some interspecific lines (A. hypogaea $\mathrm{x} A$. cardenasii) presented high yield and transgressive segregation for seed size.

Fonceka et al. (2012) detected high levels of variability for yield component traits in the $\mathrm{BC}_{3} \mathrm{~F}_{2}$ interspecific population A. hypogaea cv. Fleur 11 x (A. ipaënsis x A. duranensis ${ }^{4 \mathrm{x}}$; however, the genotypes that had better performances than the cultivated parent in number of pods per plant had similar W100S. In the 2011/12 progenies evaluation, the estimated broad-sense heritability, the coefficients of genotypic determination and $\mathrm{CVg} / \mathrm{CVe}$ ratio for pod yield and W100S were high (Table 1). These values are similar to those obtained with the $\mathrm{BC}_{3} \mathrm{~F}_{2}$ interspecific population reported by Fonceka et al. (2012), and superior to those observed for advanced cultivated lines (Gomes and Lopes 2005), indicating a favorable condition for selecting superior genotypes for these traits under the current experimental conditions. Segregating plants for yield, pod uniformity and pod shape were selected in the interspecific progenies evaluated in the 2011/12 crop season, resulting in the introduction of new 43 runner type lines in the peanut breeding program of Embrapa.

Due to phenotypical observations on yield and pod uniformity (absence of one seeded pods), progenies LPM $12,13,18,20$ and 22 were selected for yield and market evaluation in the 2012/13 crop season, under complete randomized design with four replications, in a high fertility experimental area (previously cultivated with cotton), in Santa Helena de Goiás. Pod yield, W100S, oil content and $\mathrm{O} / \mathrm{L}$ presented significant effect (Table 2); seed/pod weight ratio was similar to the cultivated control. The production recorded was much higher than the previous evaluations for all the progenies and for Runner IAC 886, probably due to the fertilizer residual from the previous crop. Pod yield did

Table 2. Means, summary of the analysis of variance and genetic parameters for pod yield and market quality evaluations of five selected peanut interspecific progenies evaluated in the 2012-13 crop seasons

\begin{tabular}{|c|c|c|c|c|c|c|c|}
\hline $\begin{array}{l}\text { Progenies } \\
\text { Runner }\end{array}$ & \multicolumn{2}{|c|}{$\begin{array}{c}\text { Pod yield } \\
\left(\mathrm{kg} \mathrm{ha}^{-1}\right)\end{array}$} & \multicolumn{2}{|c|}{ W100S (g) } & $\frac{\text { Seed ratio }}{0.79}$ & $\frac{\text { Oil content }(\%)}{47.27}$ & $\frac{\mathrm{O} / \mathrm{L} \text { ratio }}{1.82}$ \\
\hline LPM 20 & 6678.57 & $\mathrm{a}$ & 60.95 & $\mathrm{~b}$ & 0.75 & 49.07 & 1.68 \\
\hline LPM 12 & 5415.72 & $\mathrm{a}$ & 66.90 & $\mathrm{a}$ & 0.76 & 48.49 & 1.93 \\
\hline LPM 18 & 4705.31 & $\mathrm{~b}$ & 48.98 & $\mathrm{~d}$ & 0.78 & 50.16 & 1.77 \\
\hline LPM 13 & 3657.86 & $\mathrm{~b}$ & 53.88 & $\mathrm{c}$ & 0.74 & 51.79 & 1.62 \\
\hline General CV & 17.47 & & 5.99 & & 4.13 & 3.22 & 3.74 \\
\hline $\mathrm{P}$ value (progenies) & 0.002 & & 0.00004 & & 0.31 & 0.01 & 0.00008 \\
\hline $\mathrm{h}^{2}$ & 84.34 & & 92.64 & & - & 78.55 & 91.89 \\
\hline $\mathrm{CVg}$ & 20.27 & & 10.62 & & - & 3.08 & 6.27 \\
\hline $\mathrm{CVg} / \mathrm{CVe}$ & 1.16 & & 1.77 & & - & 0.96 & 1.67 \\
\hline
\end{tabular}

Means followed by the same letter in the same column belong to the same group by the Scott-Knott test at 5\% of probability. 
not differ for Runner IAC $886\left(6,805.71 \mathrm{~kg} \mathrm{ha}^{-1}\right)$, LPM 20 $\left(6,678.57 \mathrm{~kg} \mathrm{ha}^{-1}\right)$, LPM $22\left(6,192.86 \mathrm{~kg} \mathrm{ha}^{-1}\right)$ and LPM 12 $\left(5,415.72 \mathrm{~kg} \mathrm{ha}^{-1}\right)$. On the other hand, the general mean of W100S was lower when compared to the values obtained in the 2011/12 evaluation, except for LPM 22. W100S (g) ranged between 48.98 and 66.90 , and they can all be classified as runner market type. There were no differences for oil content and $\mathrm{O} / \mathrm{L}$ ratio among the treatments. As detected in the 2011/12 evaluation, the estimated broad-sense heritability, the coefficients of genotypic determination and the $\mathrm{CVg} / \mathrm{CVe}$ ratio for pod yield and $\mathrm{W} 100 \mathrm{~S}$ were high (Table 2), making feasible the selection of genotypes with high yield for the runner market.

Difficulties in selection of interspecific lines for leaf spots resistance and yield had previously and simultane- ously been reported (Stalker et al. 1979, Ouedrago et al. 1994, Santos et al. 2011), leading to the use of intensive and time consuming backcross programs, in order to recover the agronomic traits profile required for market. In the present study, high yielding interspecific progenies of runner market type with seed size for different markets were identified in the first backcross generation, attesting the potential for economic exploitation of the wild species reported by Stalker et al. (1979) and Fonceka et al. (2012). Partial resistant, high yield runner lines were selected and crossed with high yield/partial resistant cultivars to generate new breeding populations. Evaluations of these interspecific runner lines are under course aiming to select new high yield/partial resistant lines, in order to meet the growing demand of the peanut market in Brazil.

\section{Produção, padrão comercial e resistência parcial às cercosporioses de progênies interespecíficas de amendoim}

Resumo - Uma das principais demandas na cultura do amendoim é o desenvolvimento de cultivares tipo runner resistentes às cercosporioses. Na safra 2009/10, 12 progênies de pré-melhoramento (LPMs) foram selecionadas em população interespecífica $R C_{I} F_{3}$, composta de 380 plantas, para resistência às cercosporioses e características agronômicas. Em 2010/11, as 12 LPMs foram avaliadas quanto à resistência às cercosporioses. O parental recorrente (controle suscetivel) e todas as LPMs foram suscetiveis; plantas segregantes parcialmente resistentes foram selecionadas. Produtividade, vagens e sementes foram semelhantes à testemunha. Em 2011/12 as 12 LPMs e, em 2012/13, cinco LPMs selecionadas foram avaliadas quanto à produtividade e qualidade de grãos, com controle de doenças. Produtividade e peso de 100 grãos diferiram; rendimento, teor de óleo e a razão ácido oléico/linoléico foram semelhantes à testemunha. A variabilidade para resistência parcial às cercosporioses e características agronômicas, detectada após um ciclo de retrocruzamento, será útil para o Programa de Melhoramento de Amendoim.

Palavras-chave: Arachis sp., pré-melhoramento, parentes silvestres, teor de óleo, razão O/L.

\section{REFERENCES}

Amaral E (1969) Novo índice de intensidade de infecção. Pesquisa Agropecuária Brasileira 4: 1-2.

AOCS - American Oil Chemists Society (2004) Official Methods and recommended practices of the aocs, sampling and analysis of vegetable oil source materials, Section A. AOCS recommended practice Ak 5-01 approved 2001. Simultaneous determination of oil and moisture contents of oilseed residues using pulsed nuclear magnetic resonance spectrometry. In American Oil Chemists Society. Official methods and recommended practices of the AOCS. $5^{\text {th }}$ ed., AOCS, Champaign, Ill, 4p.

Backman PA and Crawford MA (1984) Relationship between yield loss and severity of early and late leaf spot diseases of peanut (Arachis hypogaea L.). Phytopathology 74: 1101-1103.

Bertioli DJ, Seijo G, Freitas FO, Valls JFM, Bertioli SCML and Moretzsohn MC (2011) An overview of peanut and its wild relatives. Plant Genetic Resources: Characterization and Utilization 9: 134-149.

Cruz CD (2006) Programa Genes: biometria. Editora UFV, Viçosa, 382p.
Cruz CD and Carneiro PCS (2006) Modelos biométricos aplicados ao melhoramento genético. $2^{\text {nd }}$ ed., Editora UFV, Viçosa, 585p.

Czermainski ABC (1999) Generalização de um índice de intensidade de infecção em experimentos de avaliação de doenças em plantas. Pesquisa Agropecuária Brasileira 34:1545-1555.

Fávero AP, Simpson CE, Valls JFM and Vello NA (2006) Study of the evolution of cultivated peanut through crossability studies among Arachis ipaënsis, A. duranensis, and A. hypogaea. Crop Science 46: $1546-1552$.

Fávero AP, Moraes SA, Garcia AAF, Valls JFM and Vello NA (2009) Characterization of rust, early and late leaf spot resistance in wild and cultivated peanut germplasm. Scientia Agricola 66: 110-117.

Fonceka D, Tossim HA, Rivallan R, Vignes H, Faye I, Ndoye O, Moretzsohn MC, Bertioli DJ, Glaszmann JC, Courtois B and Rami JF (2012) Fostered and left behind alleles in peanut: interspecific QTL mapping reveals footprints of domestication and useful natural variation for breeding. BMC Plant Biology 12: 26-42.

Grabiele M, Chalup L, Robledo G and Seijo G (2012) Genetic and geographic origin of domesticated peanut as evidenced by $5 \mathrm{~S}$ rDNA and chloroplast DNA sequences. Plant Systematics and Evolution 
TMF Suassuna et al.

298: $1151-1165$.

Gomes RLF and Lopes ACA (2005) Correlations and path analysis in peanut. Crop Breeding and Applied Biotechnology 5: 105-112.

Holbrook CC, Brenneman TB, Stalker HT, Johnson III WC, Ozias-Akins P, Chu Y, Vellidis G and McCusky (2014) Peanut. In Smith S, Diers B, Specht $J$ and Carver B (Eds.) Yield gains in major U.S. field crops. CSSA Special Publication 33, Madison, p. 173-194.

Isleib TG, Rice PW, Mozingo RW, Copeland SC, Graebera JB, Shew BB, Smith DL, Melouk HA and Stalker HT (2006) Registration of N96076L peanut germplasm line. Crop Science 46: 2329-2330.

Isleib TG, Milla-Lewis SR, Pattee HE, Copeland SC, Zuleta MC, Shew BB, Hollowell JE, Sanders TH, Dean LO and Hendrix KW (2011) Registration of 'Bailey' peanut. Journal of Plant Registrations 5: 27-39.

Kochert G, Stalker HT, Gimenes M, Galgaro L, Lopes CR and Moore K (1996) RFLP and cytogenetic evidence on the origin and evolution of allotetraploid domesticated peanut, Arachis hypogaea (Leguminosae). American Journal of Botany 83: 1282-1291.

Martins R and Vicente JR (2010) Demandas por inovação no amendoim paulista. Informacões Econômicas 40: 43-51.

Martins R (2011) Produção de amendoim e expansão da cana-de-açúcar na Alta Paulista, 1996-2010. Informações Econômicas 41: 5-16.

Moretzsohn MC, Gouvea EG, Inglis PW, Leal-Bertioli SCM, Valls JFM and Bertioli DJ (2013) A study of the relationships of cultivated peanut (Arachis hypogaea) and its most closely related wild species using intron sequences and microsatellite markers. Annals of Botany 111: 113-126.

Nass LL, Sigrist MS, Ribeiro CSC and Reifschneider FJB (2012) Genetic resources: the basis for sustainable and competitive plant breeding. Crop Breeding and Applied Biotecnology S2: 75-86.

Norden AJ, Lipscomb RW and Carver WA (1969) Registration of Florunner peanuts (Reg. n.2). Crop Science 9: p. 850.

Ouedrago M., Smith OD, Simpson CE and Smith DH (1994) Early and late leaf spot resistance and agronomic performance of nineteen interspecific derived peanut lines. Peanut Science 21: 99-104.

Santos JF, Godoy IJ, Fávero AP, Moura NF, Michelotto MD and Martins ALM (2011) Resistência a mancha preta em populações $\mathrm{F}_{4}$ selecionadas de cruzamentos entre o amendoim cultivado e um anfidiplóide de Arachis. Bragantia 70: 512-518.

Simpson CE (1993) Registration of 'TxAG-6' and 'TxAG-7' peanut germplasm. Crop Science 33: 1418.

Stalker HT, Wynne JC and Company M (1979) Variation in progenies of an Arachis hypogaea x diploid wild species hybrid. Euphytica 28: $675-684$.

Stalker HT, Beute MK, Shew BB and Isleib TG (2002) Registration of five leaf spot-resistant peanut germplasm lines. Crop Science 42:314-316.

Subrahmanyam P, Mcdonald D, Waliyar F, Reddy LJ, Nigam SN, Gibbons RW, Ramanatha VR, Singh AK, Pande S, Reddy PM and Rao PVS (1990) Ferrugem e mancha foliar tardia do amendoim: métodos de avaliação e fontes de resistência. ICRISAT, Patancheru, 20p. 